\title{
405 nm LIGHT EXPOSURE OF OSTEOBLASTS AND INACTIVATION OF BACTERIAL ISOLATES FROM ARTHROPLASTY PATIENTS: POTENTIAL FOR NEW DISINFECTION APPLICATIONS?
}

\author{
R.S. McDonald ${ }^{1,2, \S}$, S. Gupta ${ }^{1,2,3,}$, M. Maclean ${ }^{2}$, P. Ramakrishnan ${ }^{1,2}$, J.G. Anderson ${ }^{2}$, \\ S.J. MacGregor' ${ }^{2}$ R.M.D. Meek ${ }^{3}$ and M.H. Grant ${ }^{1, *}$ \\ ${ }^{1}$ Department of Biomedical Engineering, University of Strathclyde, Wolfson Centre, Glasgow, Scotland, UK \\ ${ }^{2}$ The Robertson Trust Laboratory for Electronic Sterilisation Technologies, University of Strathclyde, Glasgow, \\ Scotland, UK \\ ${ }^{3}$ Department of Trauma \& Orthopaedic Surgery, Southern General Hospital, Glasgow, Scotland, UK
}

$\S$ These authors contributed equally to the paper.

\begin{abstract}
Infection rates after arthroplasty surgery are between 1-4 \%, rising significantly after revision procedures. To reduce the associated costs of treating these infections, and the patients' post-operative discomfort and trauma, a new preventative method is required. High intensity narrow spectrum (HINS) $405 \mathrm{~nm}$ light has bactericidal effects on a wide range of medically important bacteria, and it reduced bacterial bioburden when used as an environmental disinfection method in a Medical Burns Unit. To prove its safety for use for environmental disinfection in orthopaedic theatres during surgery, cultured osteoblasts were exposed to HINS-light of intensities up to $15 \mathrm{~mW} / \mathrm{cm}^{2}$ for $1 \mathrm{~h}(54 \mathrm{~J} /$ $\mathrm{cm}^{2}$ ). Intensities of up to $5 \mathrm{~mW} / \mathrm{cm}^{2}$ for $1 \mathrm{~h}$ had no effect on cell morphology, activity of alkaline phosphatase, synthesis of collagen or osteocalcin expression, demonstrating that under these conditions this dose is the maximum safe exposure for osteoblasts; after exposure to $15 \mathrm{~mW} / \mathrm{cm}^{2}$ all parameters of osteoblast function were significantly decreased. Viability (measured by protein content and Crystal Violet staining) of the osteoblasts was not influenced by exposure to $5 \mathrm{~mW} / \mathrm{cm}^{2}$ for at least $2 \mathrm{~h}$. At $5 \mathrm{~mW} / \mathrm{cm}^{2}$ HINS-light is an effective bactericide. It killed 98.1\% of Staphylococcus aureus and $83.2 \%$ Staphylococcus epidermis populations seeded on agar surfaces, and is active against both laboratory strains and clinical isolates from infected hip and knee arthroplasties. HINS-light could have potential for development as a method of disinfection to reduce transmission of bacteria during arthroplasty, with wider applications in diverse surgical procedures involving implantation of a medical device.
\end{abstract}

Keywords: Healthcare associated infections (HAI); Highintensity narrow-spectrum (HINS) light; disinfection; $405 \mathrm{~nm}$ light; osteoblast cell cultures; bactericidal effects; Staphylococcus.

*Address for correspondence

M. Helen Grant

University of Strathclyde

Bioengineering Unit, Wolfson Centre,

06 Rottenrow, Glasgow, Strathclyde G4 0NW UK

Telephone Number: 01415483438

FAX Number: 01415526098

E-mail: m.h.grant@strath.ac.uk
Introduction

Healthcare associated infections (HAI), defined as infections which are not present at the time the patient enters hospital, are an ever increasing problem in modern healthcare affecting approximately 1 in 10 patients admitted to UK hospitals (Reilly et al., 2007). Despite current attempts to resolve the problem, including campaigns to improve hygiene in hospitals, particularly hand washing, HAI still causes significant patient mortality. A report published by the House of Commons in 2004 found that HAIs are responsible for over 5,000 deaths in the UK each year, and are a contributory factor in over 1,500 deaths (National Audit Office, 2004). In the USA, deaths associated with HAI in hospitals exceeded the number attributable to several of the top ten leading causes of death. A survey performed in 2002 found 1.7 million patients with an HAI, of which 155,668 died (Klevens et al., 2007). The rise in prevalence of HAI can partly be attributed to the increased use of antibiotics leading to antibiotic resistant strains of many bacteria (McGowan, 1983). It is clear that novel approaches to bacterial inactivation are required.

HAI take many forms. The most common type of infection reported by the Scottish National HAI Prevalence Survey was found to be urinary tract infection (UTI), accounting for $17.9 \%$ of cases (Reilly et al., 2008), with a major risk factor being the use of indwelling catheters. Surgical site infections (SSI) are the next most common, accounting for $16 \%$. The use of indwelling or implanted medical devices is increasing with technological advances, and so the incidence of device-related infection is increasing (von Eiff et al., 2005). Taking infection acquired during hip replacement surgery as a specific example of HAI, studies have shown incidence rates from 1-5\%, increasing considerably after revision procedures (Ridgeway et al., 2005; Hamilton and Jamieson, 2008; Wilson et al., 2008). During mandatory surveillance of 22,160 hip replacement procedures taking place in England between April 2004 and March 2005, Staphylococcus aureus was identified in $64 \%$ of infections, $67 \%$ of which were methicillin-resistant strains (Wilson et al., 2008). Staphylococcus epidermidis has also been identified in a large number of cases (Hamilton and Jamieson, 2008). The source of these infections is many-fold. Patient skin will contribute, but general contamination of the operation site and equipment is a 
major issue. This is particularly well documented in a paper by Davis and co-workers from Manchester, UK, reporting that $63 \%$ of operations showed contamination of the field of operation (Davis et al, 1991). A reduction in the bacterial load will therefore be beneficial. Laminar flow ventilation, by which a continuous flow of highly filtered bacteria-free air is recirculated under positive pressure into the operating field and air contaminants generated during surgery are removed from the site, was introduced to orthopaedic operating theatres in the 1980s. However, even with modern laminar flow ventilation, unacceptably high numbers of bacterial isolates are still reported during orthopaedic surgery (Owers et al., 2004), and at the British Hip Society meeting in 2011 McGovern and colleagues demonstrated how easily laminar air flow can be significantly disrupted by external forces during orthopaedic surgery (McGovern et al, 2011). Ultraviolet (UV) light in the operating theatres is more effective than laminar flow ventilation at reducing the number of airborne bacteria, and Ritter et al. (2007) reported that UV radiation reduced the risk of infection in joint replacement procedures from 1.77 to $0.57 \%$. Despite this effect, UV radiation has not been widely used in the UK as the protective clothing required by operating staff is deemed to be too hot, thick and uncomfortable for routine use (Godsen et al., 1998).

High-intensity narrow-spectrum (HINS) light is a new disinfection method that utilises the phototoxic effect of $405 \mathrm{~nm}$ visible blue light without the need for additional photosensitiser molecules (Anderson et al., 2006; Anderson et al., 2007). Although not as bactericidal as UV light, $405 \mathrm{~nm}$ light has advantages including increased human safety due to its lower photon energy (Blatchley and Peel, 1991). Previous studies have demonstrated that this $405 \mathrm{~nm}$ blue light can inactivate various bacteria, including Staphylococcus aureus, methicillin-resistant S. aureus (MRSA), S. epidermidis and Escherichia coli (Guffey and Wilborn, 2006; Maclean et al., 2008a; Maclean et al., 2009). The mechanism of bacterial inactivation is thought to be by photostimulation of endogenous intracellular porphyrins, which leads to the generation of reactive oxygen species (ROS) (Orenstein et al., 1997; Papageorgiou et al., 2000; Guffey and Wilborn, 2006; Maclean et al., 2008b). Exposure to $405 \mathrm{~nm}$ light at doses that inactivate $S$. epidermidis has been shown to not affect the viability of fibroblasts in vitro, or their contractile activity in a wound healing model - the fibroblast populated collagen hydrogel lattice (McDonald et al., 2011).

The use of $405 \mathrm{~nm}$ HINS-light for environmental disinfection has undergone clinical evaluation in occupied patient isolation rooms in Glasgow Royal Infirmary, where it was used as a background lighting system to provide continuous disinfection of air and exposed surfaces in the presence of patients and staff. The results demonstrated a significantly greater reduction in levels of environmental contamination than was achievable by normal disinfection control methods alone (Maclean et al., 2010). It is proposed that $405 \mathrm{~nm}$ HINS-light has considerable potential to reduce the environmental airborne bacterial load in orthopaedic operating theatres, and decrease the risk of post-operative infection following arthroplasty procedures. To assess the efficacy of $405 \mathrm{~nm}$ HINS-light for this application, the susceptibility of bacterial isolates from clinical cases of surgical site infections from arthroplasty procedures to HINS-light was assessed. To ensure in principle that any exposed patient bone tissue would not be detrimentally affected by exposure to lethal doses of $405 \mathrm{~nm}$ HINS-light, the effect of exposure of osteoblasts in vitro to bactericidal doses of HINS-light was determined in terms of viability, morphology and function. Osteoblast functions were assessed by alkaline phosphatase (ALP) activity, collagen synthesis and osteocalcin expression.

\section{Materials and Methods}

\section{Culture and $405 \mathrm{~nm}$ light exposure of osteoblasts}

The effect of $405 \mathrm{~nm}$ HINS-light was determined on immortalised neonatal rat calvarial osteoblasts cultured in Dulbecco's Modified Eagle's Medium (DMEM) supplemented with $10 \% \mathrm{v} / \mathrm{v}$ foetal calf serum, $1 \% \mathrm{v} / \mathrm{v}$ non-essential amino acids, penicillin (50 units $/ \mathrm{mL}$ ) and streptomycin $(50 \mu \mathrm{g} / \mathrm{mL})$. Cells were routinely cultured as monolayers in $75 \mathrm{~cm}^{2}$ tissue culture flasks in a humidified atmosphere of $5 \% \mathrm{CO}_{2}$ in air at $37^{\circ} \mathrm{C}$. For experimental use, the required cell concentration was prepared in complete DMEM and seeded onto the surface of multiwell plates $(0.2 \mathrm{~mL}$ for 96 -well plates; $1 \mathrm{~mL}$ for 24 -well plates), with the seeding density used $\left(5 \times 10^{3}\right.$ cells $/ \mathrm{cm}^{2}$ or $2 \times 10^{4}$ cells $\left./ \mathrm{cm}^{2}\right)$ determined by the post-exposure test being performed. After seeding, cells were incubated for a minimum of $4 \mathrm{~h}$ to allow attachment, and then the culture medium was replaced with Dulbecco's phosphate buffered saline (PBS) for $405 \mathrm{~nm}$ HINS-light exposure.

The HINS-light system consisted of a bank of nine narrow-band LEDs (GE Lumination, Cleveland, $\mathrm{OH}$, USA), with peak output at $405 \mathrm{~nm}$ and a $20 \mathrm{~nm}$ bandwidth at full-width half-maximum, attached to a heat sink supported by two pillars above a moulded base which centralises the position of the treatment dish. The distance between the sample and the LEDs was $8 \mathrm{~cm}$. This short distance was chosen to optimise chances of seeing any deleterious effects of the HINS-light exposure in the experimental set up. The heat sink ensured that the operating temperatures remained constant for the duration of the light treatments, and no heating of samples occurred. Cells were exposed to $1 \mathrm{~h}$ durations of $405 \mathrm{~nm}$ light with irradiance levels of $0.5,1.8,5$ and $15 \mathrm{~mW} / \mathrm{cm}^{2}$, corresponding to doses of 1.8 , $6.5,18$ and $54 \mathrm{~J} / \mathrm{cm}^{2}$. Control cells that were not exposed to HINS-light were incubated in PBS for an equivalent time. The effect of prolonged exposure times was investigated for up to $3 \mathrm{~h}$ in terms of cell viability. After exposure, PBS was removed and the cells were incubated in fresh media until required for assessment of osteoblast function, with media being refreshed every 2-3 days for the duration of the experiment.

\section{Markers of osteoblast function}

Cells were seeded at $2 \times 10^{4}$ cells $/ \mathrm{cm}^{2}$ in 96 -well plates for measurement of alkaline phosphatase (ALP) activity, collagen synthesis and osteocalcin expression. ALP activity was measured at 24 and $72 \mathrm{~h}$ post-exposure to $405 \mathrm{~nm}$ 
HINS-light at irradiances between 0.5 and $15 \mathrm{mWcm}^{2}$ by the dephosphorylation of p-nitrophenyl phosphate (pNPP; $1 \mathrm{mg} / \mathrm{mL}$ ). DMEM was removed, wells washed with PBS, and $200 \mu \mathrm{L}$ of $1 \mathrm{mg} / \mathrm{mL}$ pNPP in $0.1 \mathrm{M}$ glycine buffer, $\mathrm{pH} 10.4$, containing $1 \mathrm{mM} \mathrm{MgCl}_{2}$ and $1 \mathrm{mMZnCl}_{2}$ added to each well. pNPP is dephosphorylated to $\mathrm{p}$-nitrophenol and phosphate in the presence of ALP, and the resultant release of p-nitrophenol was detected at $405 \mathrm{~nm}$ immediately and 15 min after addition and calculated using the extinction coefficient of p-nitrophenol $(18.75 \mathrm{mM} / \mathrm{cm})$ (Bowers and McComb, 1966).

Collagen synthesis by the osteoblasts was assessed by the method of Walsh et al. (1992). At 24 and 72 h postexposure to $405 \mathrm{~nm}$ HINS-light at irradiances between 0.5 and $15 \mathrm{mWcm}^{2}$, the cells were fixed by Bouin's solution, and stained with picrosirius red stain for $1 \mathrm{~h}$. Following a wash with $0.01 \mathrm{M} \mathrm{HCl}$, cells were solubilised in $0.25 \mathrm{M}$ $\mathrm{NaOH}$, and the absorbance quantified at $550 \mathrm{~nm}$ using a standard curve obtained with collagen type I. Picrosirius red staining was also used to visualise the cells using the above procedure carried out on cells cultured on $10 \mathrm{~mm}$ diameter glass slides in 24-well plates at the same seeding density. Instead of solubilising the cells post-staining, they were visualised with bright field microscopy (Zeiss Axioimager microscope; Zeiss, Oberkochen, Germany).

Osteocalcin secreted into the medium 3, 6 and 10 days after exposure of cells to $405 \mathrm{~nm}$ HINS-light at irradiances between 1.8 and $15 \mathrm{mWcm}^{2}$ was measured with an ELISA kit (BT-490, Biomedical Technologies, Stoughton, MA, USA) according to the manufacturer's instructions. Production of osteocalcin by the osteoblasts was maximised by treating the cells for 3 days with $10^{-8} \mathrm{M}$ 1,25-dihydroxy vitamin $\mathrm{D}_{3}$ (Martinez et al., 2001).

Scanning electron microscopy was carried out on $2 \times 10^{4} / \mathrm{cm}^{2}$ cells cultured on $10 \mathrm{~mm}$ diameter poly-1-lysine coated glass slides. Immediately after exposure to $405 \mathrm{~nm}$ HINS-light cells were fixed with $2.5 \%$ glutaraldehyde, then treated with $1 \%$ osmium tetroxide and uranyl acetate, before being critical point dried through a series of alcohols, sputter coated with a gold/palladium mixture and viewed at magnifications ranging from $\times 250$ to $\times 30000$ at $10 \mathrm{kV}$.

\section{Measurement of viability}

The total protein content of the osteoblasts attached to the culture dishes was determined 2 and 3 days after exposure to $5 \mathrm{~mW} / \mathrm{cm}^{2}$ HINS-light for between 1 and $3 \mathrm{~h}$. After seeding at $5 \times 10^{3}$ cells $/ \mathrm{cm}^{2}$ in 24 -well plates the total protein was measured by the Lowry assay (Lowry et al., 1951) after solubilising the cells in $0.5 \mathrm{M} \mathrm{NaOH}$ overnight. Crystal violet staining of cellular DNA in attached cells was quantified after fixing the cell monolayers with formalin, for $30 \mathrm{~min}$ followed by staining with $1 \mathrm{mg} / \mathrm{mL}$ Crystal Violet for $20 \mathrm{~min}$. The stain was solubilised with $0.1 \%$ Triton X-100 in PBS for $24 \mathrm{~h}$ on a rotary plate before measuring the absorbance at $540 \mathrm{~nm}$.

Culture and $405 \mathrm{~nm}$ HINS-light exposure of bacterial pathogens

Culture collection strains of Staphylococcus aureus NCTC 4135 and Staphylococcus epidermidis NCTC 11964 were obtained from the National Collection of Type Cultures (Collindale, UK). Clinical bacterial isolates used in this study were Staphylococcus aureus, Staphylococcus epidermidis, Corynebacterium striatum, Enterococcus faecalis, Micrococcus sp., Escherichia coli, Klebsiella pneumoniae, Serratia marcescens and Pseudomonas aeruginosa. All clinical isolates were isolated from infected hip and knee arthroplasties, and were obtained from the Southern General Hospital Microbiology Department (Glasgow, UK).

For experimental use, bacterial species were inoculated into $100 \mathrm{~mL}$ broth (Oxoid/Thermo Fisher Scientific, Basingstoke, UK) and incubated at $37{ }^{\circ} \mathrm{C}$ for $18 \mathrm{~h}$ under rotary conditions (120 rpm). All microorganisms were cultured in Nutrient Broth (Oxoid/Thermo Fisher Scientific) with the exception of $C$. striatum, which was inoculated in Brain Heart Infusion Broth (Oxoid/ Thermo Fisher Scientific). After incubation, cultures were centrifuged at $3939 \times \mathrm{g}$ for $10 \mathrm{~min}$ and the microbial cell pellet was then re-suspended in $100 \mathrm{~mL}$ PBS. Bacterial suspensions were diluted to a population density of $10^{3}$ colony-forming units per millilitre $(\mathrm{CFU} / \mathrm{mL})$. For $405 \mathrm{~nm}$ light exposure, $100 \mu \mathrm{L}$ microbial suspensions were seeded onto agar plates, providing a population of approximately 100-300 CFU/agar plate. Nutrient agar was used for all bacterial species except $C$. striatum, which was seeded onto blood agar (Oxoid/Thermo Fisher Scientific).

For exposure of $S$. aureus NCTC 4135 and S. epidermidis NCTC 11964, the $405 \mathrm{~nm}$ HINS-light source used was the same as that used for exposure of the osteoblast cells. Microbial samples were exposed to $1 \mathrm{~h}$ durations of $405 \mathrm{~nm}$ light with an irradiance level of $5 \mathrm{~mW} / \mathrm{cm}^{2}(\sim 18 \mathrm{~J} /$ $\mathrm{cm}^{2}$ ). Post-exposure, plates were incubated at $37{ }^{\circ} \mathrm{C}$ for $24 \mathrm{~h}$ before enumeration. Results represent the mean of a minimum of triplicate replicates, and are reported as the percentage of surviving CFU/plate, as compared to non-exposed control samples. To determine the biocidal activity of $405 \mathrm{~nm}$ HINS-light against the range of clinical infected arthroplasty isolates, a $405 \mathrm{~nm}$ LED array with 144 LEDs (Enfis/Photonstar Technology, Romsey, Hampshire, UK) was used which provided an average irradiance of $71 \mathrm{~mW} / \mathrm{cm}^{2}$ across the diameter of the agar surface. This higher power $405 \mathrm{~nm}$ light source provided higher irradiance, thereby providing a more rapid and convenient exposure system for determination of the susceptibility of the range of arthroplasty isolates to $405 \mathrm{~nm}$ light. Isolates seeded on the agar surfaces were exposed to increasing durations of light treatment (between $2.5 \mathrm{~min}$ to $1 \mathrm{~h}$ ), and non-exposed control plates were set-up for all samples. As with the culture collection isolates, results are reported as the percentage of surviving $\mathrm{CFU} /$ plate, as compared to non-exposed control samples.

\section{Statistical analysis}

Data were compared by ANOVA followed by Dunnett's post-hoc test, unless otherwise stated, and significance was assigned at $p<0.05$. 


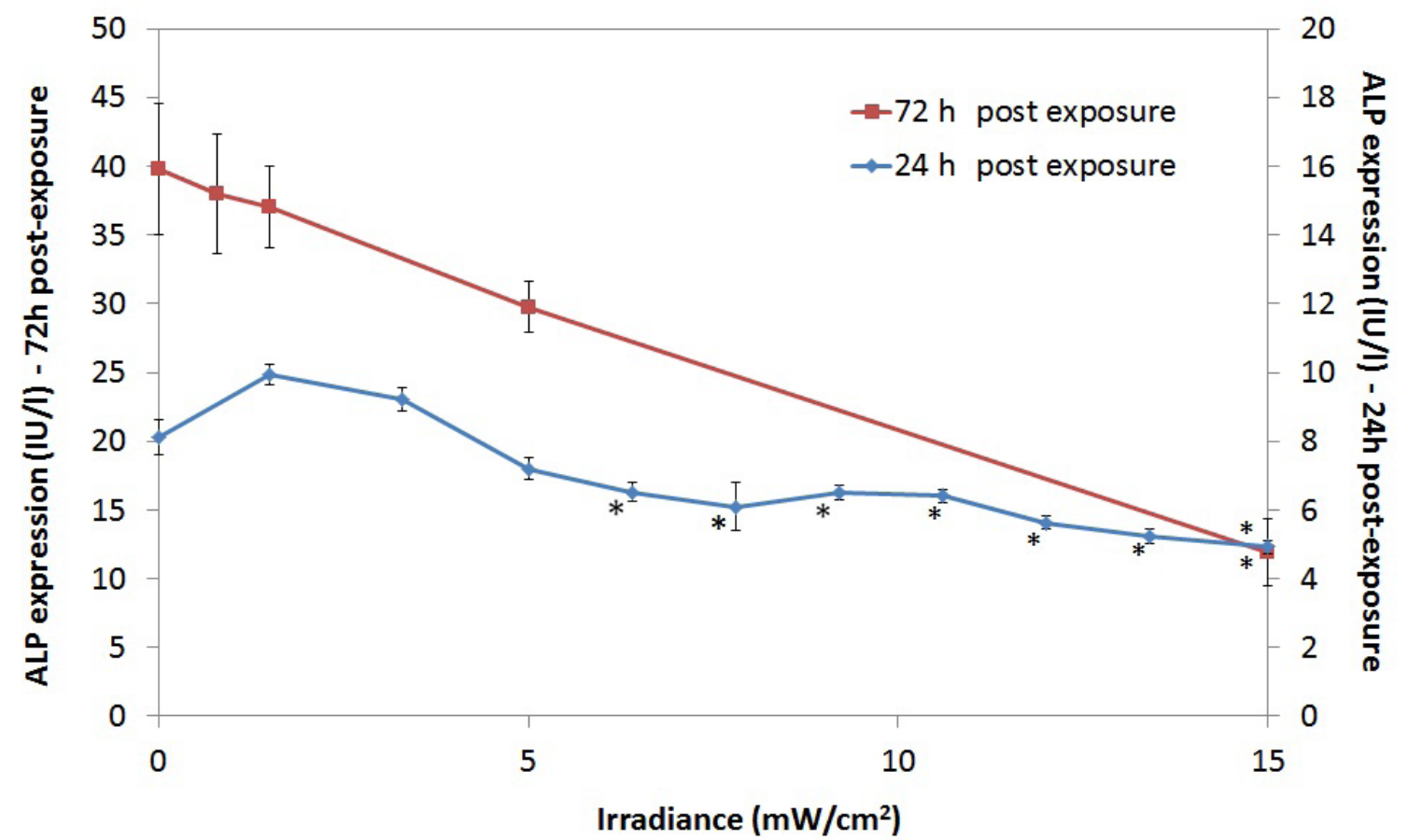

Fig. 1. ALP expression at $24(\diamond)$ and $72(\boldsymbol{\square})$ hours post-exposure of osteoblasts treated at between 0.5 and $15 \mathrm{~mW} /$ $\mathrm{cm}^{2}$. $*$ indicates significant difference from control $(p<0.05$, ANOVA followed by Dunnett's comparison, $n=3$ independent experiments \pm SEM). Note that the data at $24 \mathrm{~h}$ should be read off the $\mathrm{y}$ axis on the right of the graph, and those for $72 \mathrm{~h}$ from the axis on the left of the graph.

\section{Results}

\section{Effect of $405 \mathrm{~nm}$ HINS-light exposure on osteoblast function}

The function of osteoblasts following exposure to $405 \mathrm{~nm}$ HINS-light was monitored by ALP activity and by the ability to synthesise collagen and osteocalcin.

A $1 \mathrm{~h}$ exposure to intensities of $405 \mathrm{~nm}$ HINS-light at or below $5 \mathrm{~mW} / \mathrm{cm}^{2}\left(18 \mathrm{~J} / \mathrm{cm}^{2}\right)$ caused no significant reduction in activity of ALP at $24 \mathrm{~h}$ post-exposure. Intensities above $5 \mathrm{~mW} / \mathrm{cm}^{2}$ caused a statistically significant decrease in ALP activity. By $72 \mathrm{~h}$ post-exposure, osteoblasts treated at $15 \mathrm{~mW} / \mathrm{cm}^{2}$ showed minimal signs of recovery. Cells exposed to $5 \mathrm{~mW} / \mathrm{cm}^{2} \mathrm{HINS}$-light and below did not show a significant decrease in ALP activity compared with the control at $72 \mathrm{~h}$ post-exposure (Fig. 1).

Differential interference contrast (DIC) microscopy images of control cells and cells exposed to $1 \mathrm{~h}$ of $15 \mathrm{~mW} /$ $\mathrm{cm}^{2}$ HINS-light stained with picrosirius red for the presence of collagen are shown in Fig. 2 (A) and (B) respectively. Microscopy was performed at $48 \mathrm{~h}$ following exposure. Osteoblasts exposed to $15 \mathrm{~mW} / \mathrm{cm}^{2}$ retained the elongated shape of healthy osteoblasts and no obviously damaged cells were present in the sample. Collagen synthesis was not affected by exposure to up to $5 \mathrm{~mW} / \mathrm{cm}^{2} \mathrm{HINS}$-light, at either 24 or $72 \mathrm{~h}$ post-exposure. A significant decrease in synthesis was shown in osteoblasts exposed to $15 \mathrm{~mW} /$ $\mathrm{cm}^{2}$ HINS-light at $24 \mathrm{~h}$ post-exposure, and this significant decrease persisted at $72 \mathrm{~h}$ post-exposure (Fig. 3) with no sign of recovery.

No decrease was observed in osteocalcin expression by osteoblasts exposed to $5 \mathrm{~mW} / \mathrm{cm}^{2}$ or lower HINS-light for
$1 \mathrm{~h}$ at up to 10 days post-exposure. However, expression was significantly suppressed in osteoblasts exposed to HINS-light intensities of $15 \mathrm{~mW} / \mathrm{cm}^{2}$ for $1 \mathrm{~h}$ at 3 and 6 days post-exposure (Fig. 4). By 10 days post-exposure, expression of osteocalcin in cells exposed to $1 \mathrm{~h}$ of $15 \mathrm{~mW} /$ $\mathrm{cm}^{2}$ was not significantly different from the control.

To detect any effects on cell morphology, scanning electron microscopy was performed on cells immediately following a $1 \mathrm{~h}$ exposure to 5 and $15 \mathrm{~mW} / \mathrm{cm}^{2}$ HINSlight. Cells that had not been exposed to HINS-light had classic osteoblast morphology (Fig. 5A). They appear well attached and stretched out, and high magnification images of individual cells showed no remarkable surface features. Osteoblasts exposed to $1 \mathrm{~h}$ at $5 \mathrm{~mW} / \mathrm{cm}^{2}$ appeared to be similar to the controls (Fig. 5B), but after exposure to $15 \mathrm{~mW} / \mathrm{cm}^{2}$ they had a noticeably different appearance compared to control cells (Fig. 5C). Although the cell density appeared similar, the proportion of cells that were attached and stretched out was less. Higher magnification images of the cell surface showed many small imperfections, like cuts or folds in the membrane, suggesting some sub-lethal effects on the cells (Fig. 5C). A summary of the effects of the maximum dose $(15 \mathrm{~mW} /$ $\mathrm{cm}^{2}$ for $1 \mathrm{~h}$ ) of HINS-light on the cells is shown in Table 1.

Having determined that exposure to $5 \mathrm{~mW} / \mathrm{cm}^{2}$ for $1 \mathrm{~h}$ was a safe dose of $405 \mathrm{~nm}$ HINS-light in terms of the osteoblast functions, cells were exposed to this irradiance level of light for up to $3 \mathrm{~h}$ to establish the maximum duration this irradiance of light could be used safely. Viability of the cells in culture was measured 48 and $72 \mathrm{~h}$ post-exposure by both total protein content and DNA 


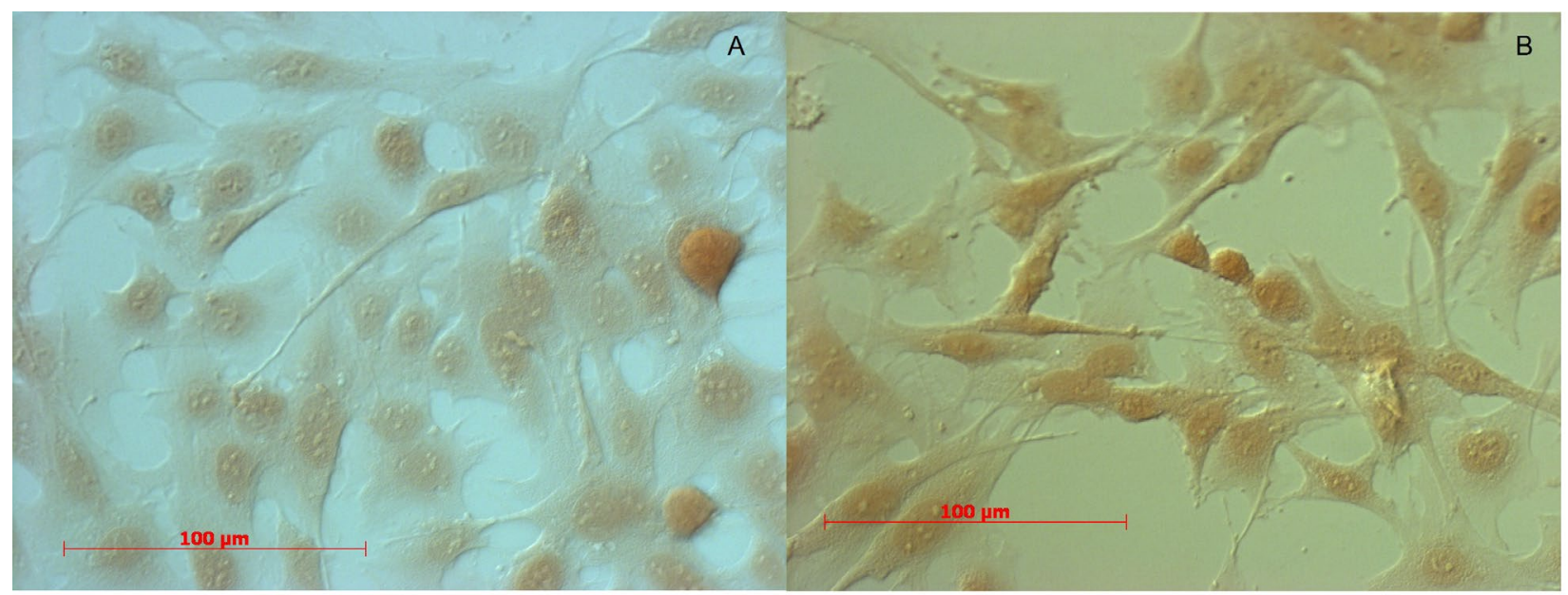

Fig. 2. DIC microscopy images of osteoblasts stained with picrosirius red. Image (A) and (B) show control cells and those exposed to $15 \mathrm{~mW} / \mathrm{cm}^{2} \mathrm{HINS}$-light for $1 \mathrm{~h}$, respectively, at $48 \mathrm{~h}$ post-exposure.

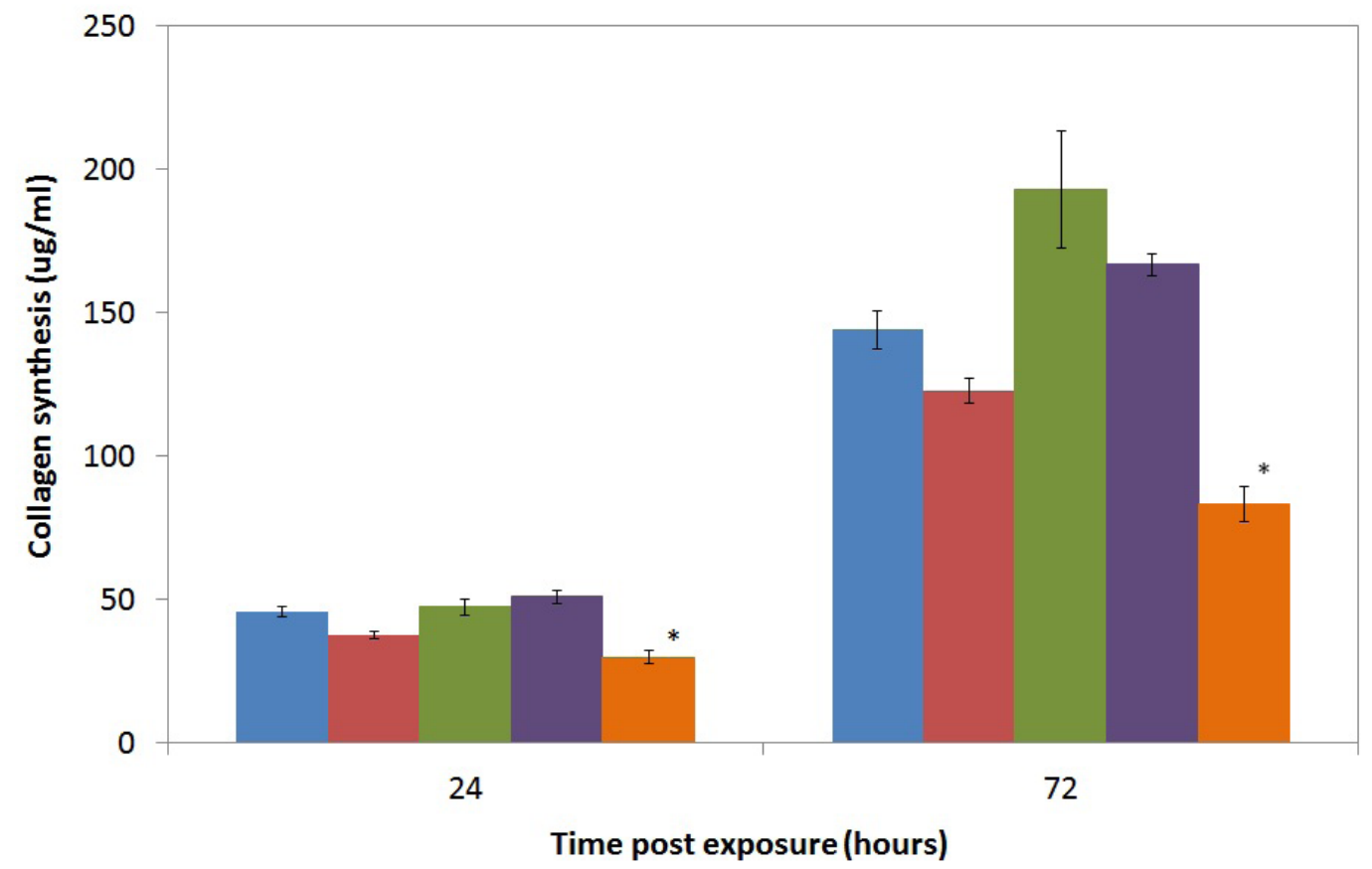

Fig. 3. Collagen synthesis by osteoblasts exposed to HINS-light. Cells were exposed to (from left to right at each time point); control, $0.5 \mathrm{~mW} / \mathrm{cm}^{2}, 1.8 \mathrm{~mW} / \mathrm{cm}^{2}, 5 \mathrm{~mW} / \mathrm{cm}^{2}$ and $15 \mathrm{~mW} / \mathrm{cm}^{2}$ for $1 \mathrm{~h}$. * indicates significant difference from control ( $p<0.05$, ANOVA followed by Dunnett's comparison, $n=3$ independent experiments $\pm \mathrm{SEM}$ ).

staining with Crystal Violet in attached cells. Data in Fig. 6 show that cells tolerated exposure to $5 \mathrm{~mW} / \mathrm{cm}^{2} \mathrm{HINS}$ light for up to $120 \mathrm{~min}$ without significant loss of viability, but $3 \mathrm{~h}$ exposure resulted in a significant difference in the number of viable attached cells compared with the cells exposed for $60 \mathrm{~min}$.

\section{Effect of $405 \mathrm{~nm}$ HINS-light exposure on bacterial pathogens}

Osteoblast exposure determined that $1 \mathrm{~h}$ exposure to $5 \mathrm{~mW} / \mathrm{cm}^{2}$ light was non-detrimental to the osteoblast cells. Experiments were carried out to assess whether this level of exposure could induce a bactericidal effect in $S$. aureus and S. epidermidis. Results, shown in Table 2, demonstrate that exposure to $5 \mathrm{~mW} / \mathrm{cm}^{2}$ for $1 \mathrm{~h}$ successfully reduced bacterial contamination, with a $98 \%$ and $83 \%$ reduction in population achieved with $S$. aureus and S. epidermidis, respectively.

Exposure of a range of clinical isolates from infected arthroplasties demonstrated that $405 \mathrm{~nm}$ HINS-light has a non-selective bactericidal effect, with successful inactivation achieved across a wide range of Gram-positive and Gram-negative species (Fig. 7A and B, respectively). Inactivation of Gram-positive species appeared to occur at a slightly faster rate with $>90 \%$ inactivation occurring between 5-30 min, compared to 10-60 min for the Gramnegative species. When comparing the inactivation data for the clinical $S$. aureus and $S$. epidermidis isolates with those of the culture collection isolates it can be seen that use of the higher irradiance of $71 \mathrm{~mW} / \mathrm{cm}^{2}$ resulted in much faster inactivation than when using the lower $5 \mathrm{~mW} / \mathrm{cm}^{2}$ irradiance; $90-100 \%$ inactivation in 5-10 min compared 


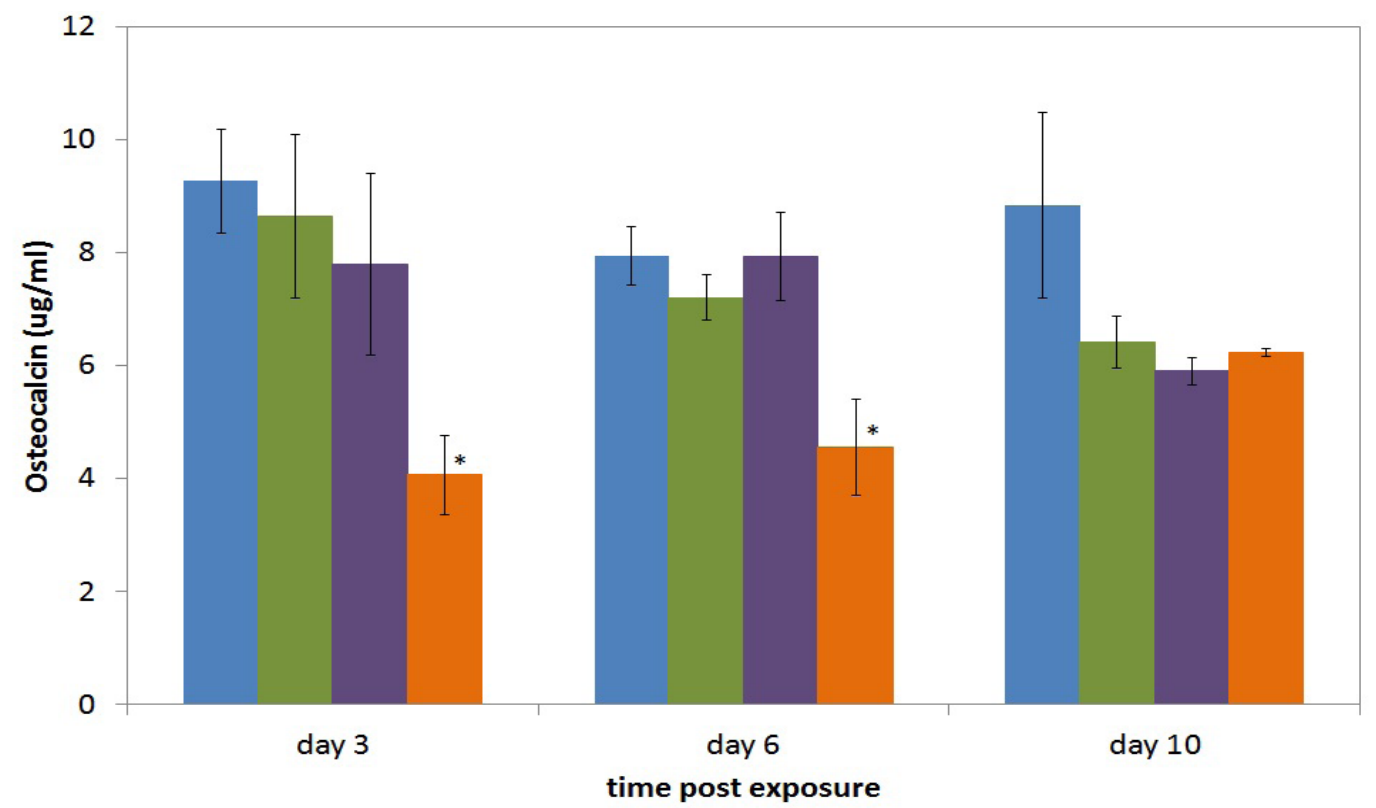

Fig. 4. Osteocalcin expression following $1 \mathrm{~h}$ HINS-light exposure. From left to right at each timepoint; control, $1.8 \mathrm{~mW} / \mathrm{cm}^{2}, 5 \mathrm{~mW} / \mathrm{cm}^{2}, 15 \mathrm{~mW} / \mathrm{cm}^{2}$. * indicates significant difference from control $(p<0.05$, ANOVA followed by Dunnett's comparison, $n=3$ independent experiments $\pm \mathrm{SEM}$, except for control and $15 \mathrm{~mW} / \mathrm{cm}^{2}$ samples on days 3 and 6 where $n=6$ ).

to $80-100 \%$ after $1 \mathrm{~h}$. These results demonstrate that the higher the irradiance of $405 \mathrm{~nm}$ light, the faster the rate of bacterial inactivation that can be achieved.

\section{Discussion}

The results of this study demonstrate that intensities of HINS-light of $5 \mathrm{~mW} / \mathrm{cm}^{2}$ and below applied over $1 \mathrm{~h}$, do not have a significant effect on osteoblast function in terms of ALP activity, collagen synthesis and osteocalcin secretion. It is important to state that in all experiments carried out on osteoblasts in this study, culture medium was replaced with phosphate buffered saline (PBS) for the duration of HINS-light exposure due to possible generation of ROS in the culture medium. Cell viability has been shown to be significantly reduced by exposure to visible and near-UV radiation when exposed in culture medium compared to PBS (Stoien and Wang, 1974; Smith, 2009). The main component of culture medium responsible for ROS generation has been shown to be riboflavin, with tryptophan, tyrosine, pyridoxine and folic acid all enhancing the effect (Grzelak et al., 2001).

In vitro, ALP activity is well established as a measure of osteoblast ability to synthesise bone (Hoemann et al., 2009), and it is encouraging to find that exposure to $5 \mathrm{~mW} /$ $\mathrm{cm}^{2}$ for $1 \mathrm{~h}$ has no inhibitory effect on the activity either immediately, or after 24 or $72 \mathrm{~h}$ post-exposure. As the intensity was increased from 5 to $15 \mathrm{~mW} / \mathrm{cm}^{2}$ significant decreases relative to control values were observed at both 24 and $72 \mathrm{~h}$ post-exposure. The effect of blue light on ALP activity has not previously been investigated in osteoblasts. Low doses of red laser light have been shown to be without significant effect (Khadra et al., 2005) but inhibition at high doses $\left(2 \mathrm{~J} / \mathrm{cm}^{2}\right)$ of light at a wavelengths of $670 \mathrm{~nm}$ has been reported (Stein et al., 2005).

Collagen synthesis is an essential aspect of bone matrix formation by osteoblasts, and the effects of $405 \mathrm{~nm}$ HINSlight exposure on this parameter were found to be similar to the effect on ALP activity. Exposure to intensities of up to $5 \mathrm{~mW} / \mathrm{cm}^{-2}$ for up to $1 \mathrm{~h}$ had no significant effect on the ability of osteoblasts to synthesise collagen, while exposure to higher intensities significantly reduces this function. Although collagen synthesis has been shown to be both stimulated (Stein et al., 2005; Saracino et al., 2009) and inhibited (Marques et al., 2004) by laser irradiation, there are no studies in the literature using an equivalent irradiance of light to that used in the present study. Staining of the collagen with picrosirius red and visualising the stained cells by microscopy proved not to be sensitive enough to detect the inhibition of synthesis in the cells, but revealed the morphology of the cells post-exposure to $405 \mathrm{~nm}$ HINS-light very clearly. There was no visible evidence of a change in cell morphology, or the presence of apoptotic cells.

Osteocalcin is the most abundant non-collagenous protein produced by osteoblasts, and studies on knock-out mice suggest that it has osteogenic regulatory functions (Ducy et al., 1996). The ELISA kit used in this study has been shown to be an effective reliable method for determining osteogenic potential (Nakamura et al., 2009). As reported previously, osteoblasts did not secrete measurable amounts of osteocalcin without stimulation with the hormone 1,25-dihydroxy vitamin $\mathrm{D}_{3}$ (Carpenter et al., 1998). Expression of osteocalcin is lower during the log phase of growth of the osteoblasts, and at maximum levels once the cells have reached confluence as reported previously (Owen et al., 1991). Measuring osteocalcin production 3 days after exposure showed that $405 \mathrm{~nm}$ 


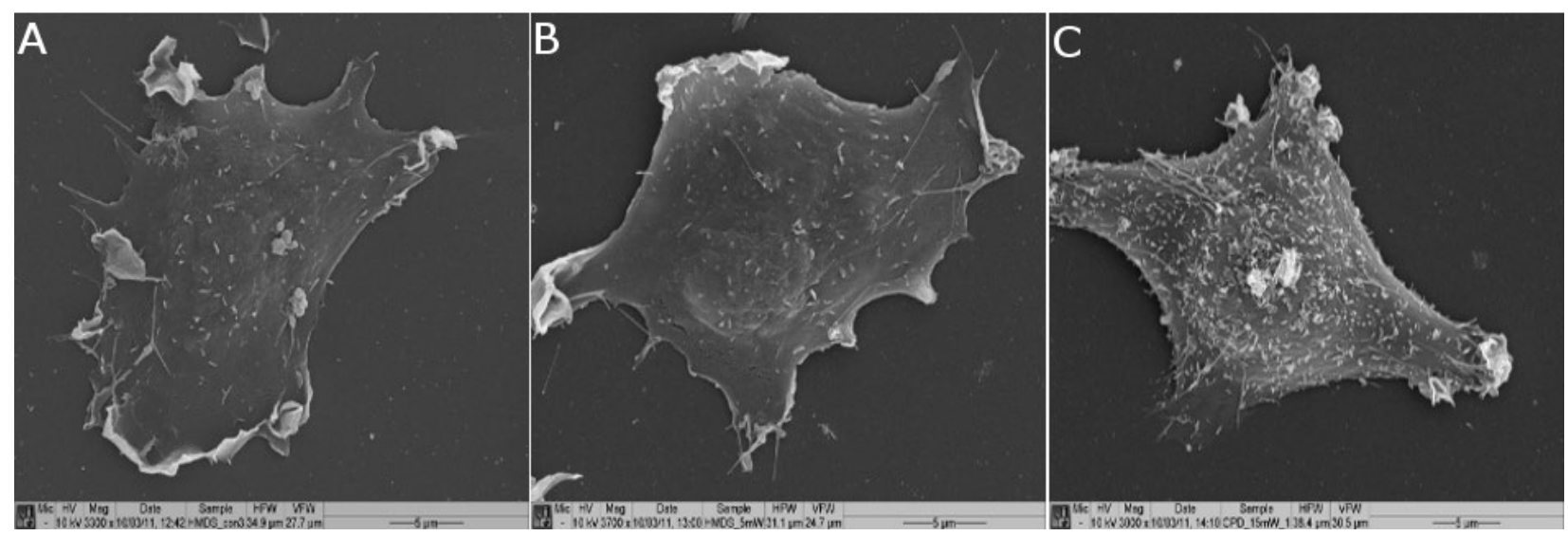

Fig. 5. SEM micrographs showing the effect of a $1 \mathrm{~h}$ exposure to 5 and $15 \mathrm{~mW} / \mathrm{cm}^{2}$ (B and C) HINS-light on osteoblast morphology. Control (A). Scale bars are $5 \mu \mathrm{m}$.

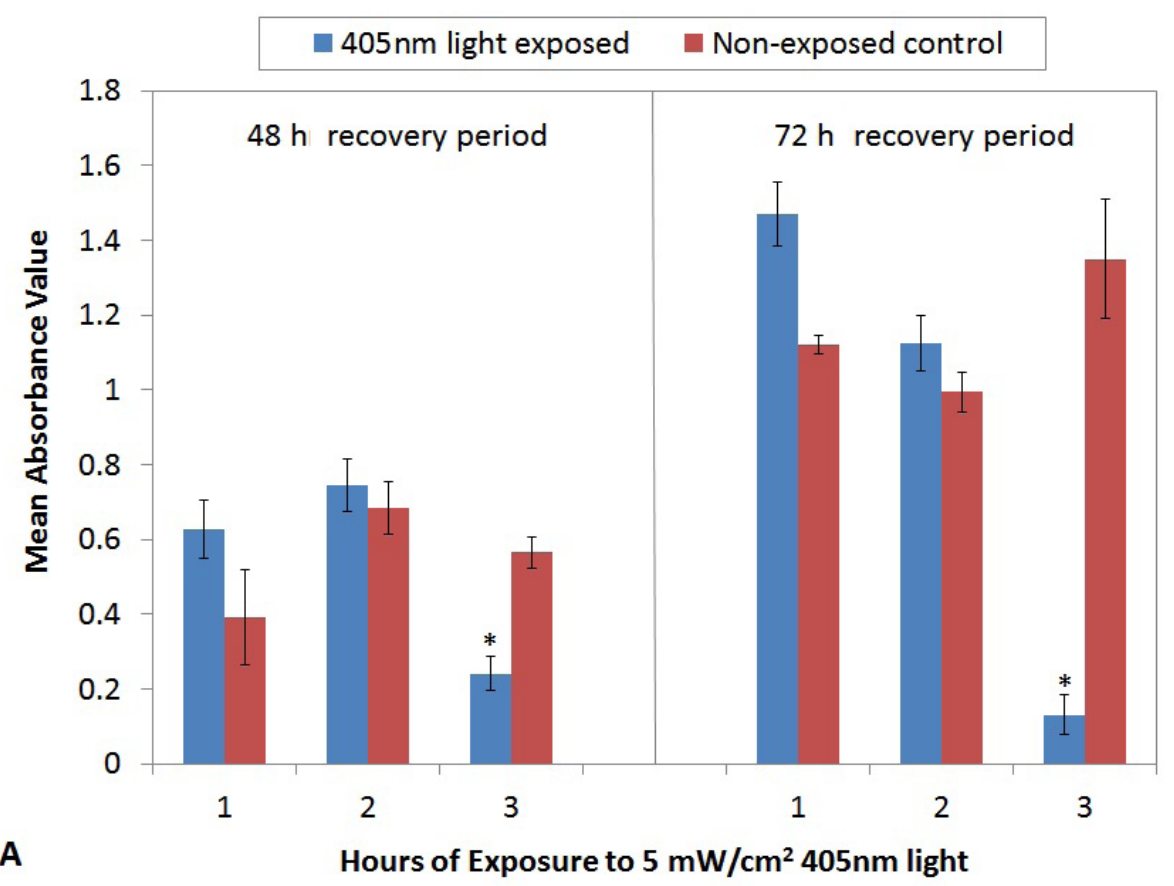

Fig. 6. Viability of osteoblasts following exposure to $5 \mathrm{~mW} /$ $\mathrm{cm}^{2}$ HINS-light for 1, 2 and 3 h. A shows the Crystal Violet staining of cultures incubated in the presence of $5 \mathrm{~mW} / \mathrm{cm}^{2}$ HINS-light, and control cultures incubated in the absence of HINS-light. B shows the protein content of cultures incubated in the presence of $5 \mathrm{~mW} / \mathrm{cm}^{2}$ HINS-light, and control cultures incubated in the absence of HINS-light. $\left({ }^{*} p<0.05\right.$, unpaired student $t$-test, comparing the controls and HINS light treated samples after the same exposure time, $n=4$ independent experiments \pm SEM).

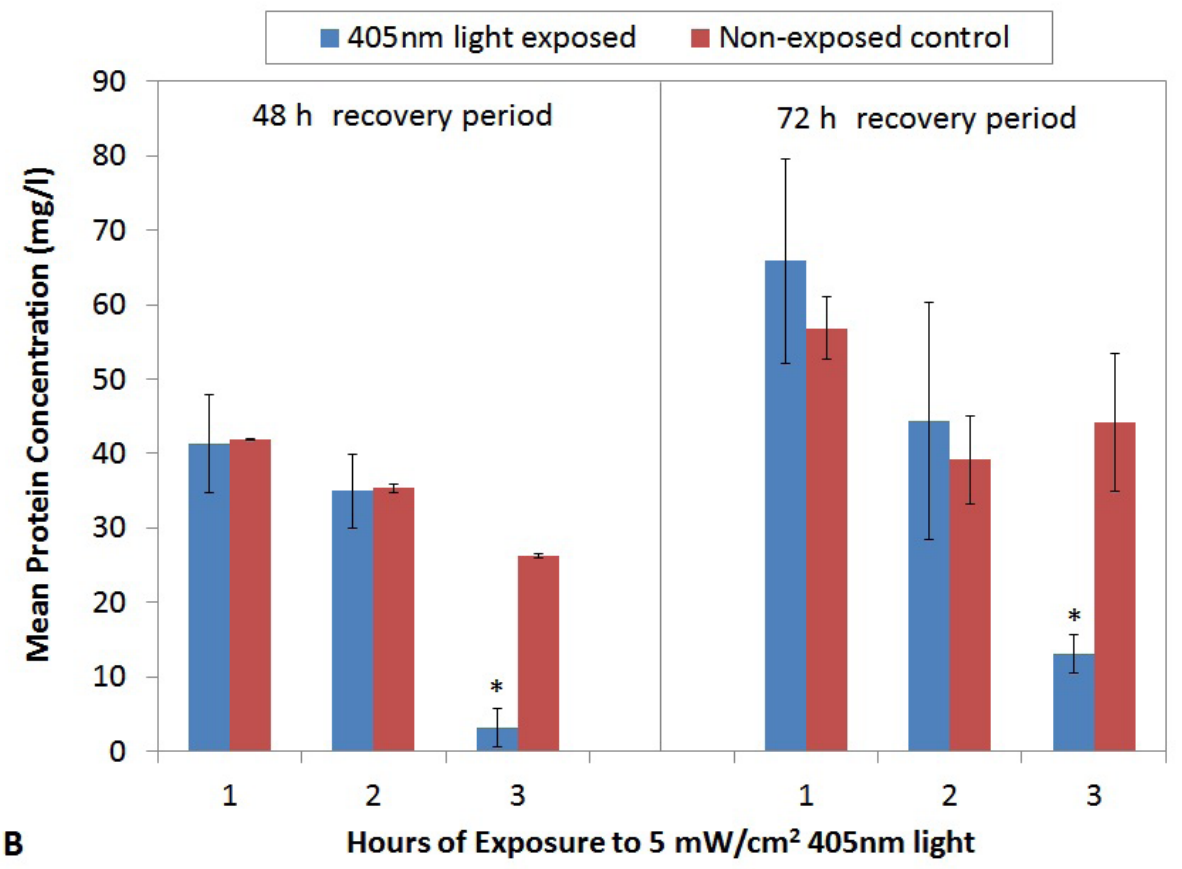



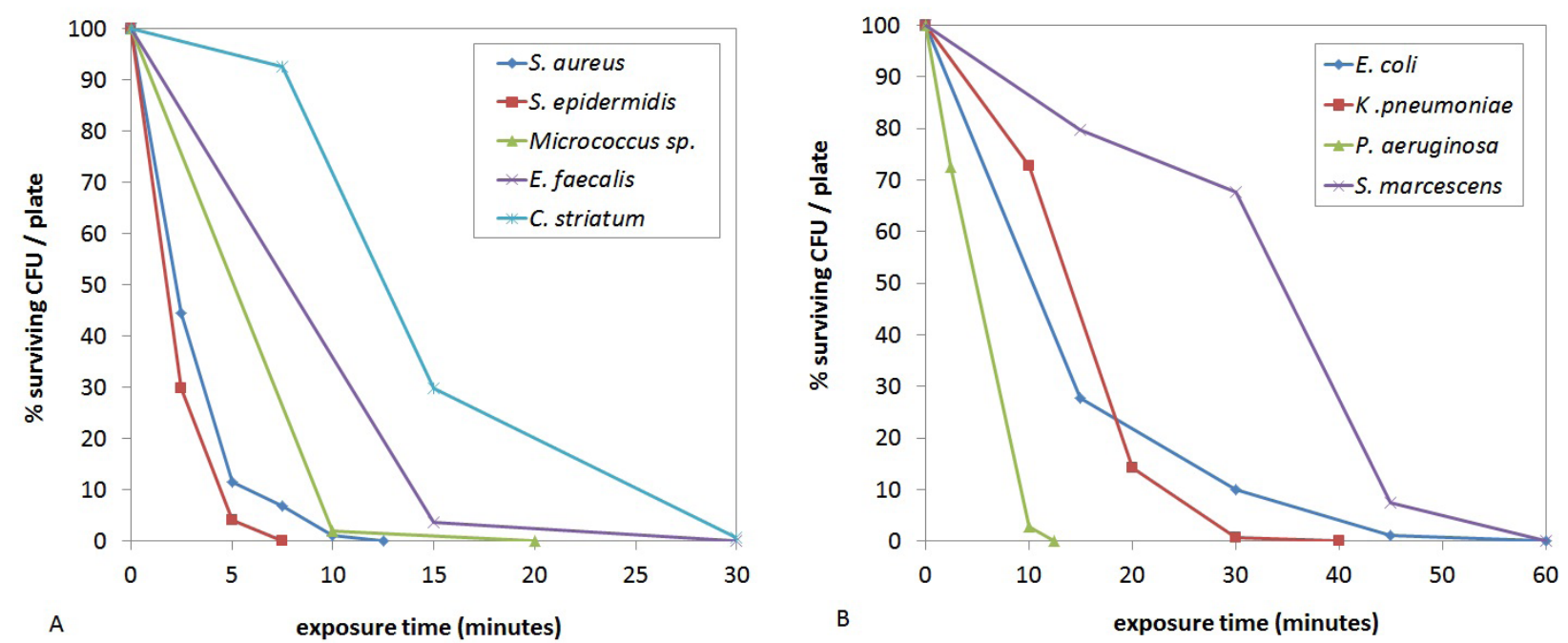

Fig. 7. Inactivation of a range of Gram positive (A) and Gram negative (B) clinical isolates from infected arthroplasties. Bacterial isolates were exposed on agar plate surfaces using $405 \mathrm{~nm}$ HINS-light with an average irradiance of $71 \mathrm{~mW} / \mathrm{cm}^{2}$.

HINS-light doses of up to $5 \mathrm{~mW} / \mathrm{cm}^{2}$ did not significantly affect expression, whereas exposure to $15 \mathrm{~mW} / \mathrm{cm}^{2}$ caused a significant reduction, from which the cells had recovered 10 days after exposure. There are no data in the literature on the effect of blue light on osteocalcin expression in osteoblasts, but near-UV laser irradiation has been shown to stimulate osteocalcin production in human osteoblasts (Khadra et al., 2005).

SEM analyses showed that exposure to $5 \mathrm{~mW} / \mathrm{cm}^{2}$ did not cause any visible difference to the cell morphology compared to control cells, and the density of the cells was not significantly reduced. However, after the osteoblasts were exposed to $15 \mathrm{~mW} / \mathrm{cm}^{2}$ for $1 \mathrm{~h}$ there was undoubtedly some disturbance caused to the membrane of the cells. The resolution of the images is not high enough to identify the features, but they may represent the initial stage of bleb formation. The decrease in surface area observed after exposure to $15 \mathrm{~mW} / \mathrm{cm}^{2}$ HINS-light confirms an effect on the cells, and may represent the shrinking associated with apoptosis. A lesser percentage of cells in this group had the stretched morphology and associated large surface seen in the control cells.

The results demonstrate that $405 \mathrm{~nm}$ HINS-light has a dose dependent effect on osteoblast function. They imply that irradiances of up to $5 \mathrm{~mW} / \mathrm{cm}^{2}$ delivered over a period of $2 \mathrm{~h}$ should not cause damaging effects to osteoblasts during procedures such as hip replacement, which result in exposure of bone surfaces to the external environment. The time required for implantation of a primary hip arthroplasty is approximately $1 \mathrm{~h}$ surgery, and a revision operation is considerably longer; 2 to $2.5 \mathrm{~h}$ depending on the complexity of the case. The data shown here illustrate that exposure to HINS-light, under the conditions used for up to $120 \mathrm{~min}$, does not significantly alter osteoblast viability. However, we recognise that the cells used were derived from rat tissue, and there may be differences in the responses of human cells.

Despite the finding that a $1 \mathrm{~h}$ exposure to $15 \mathrm{~mW} /$ $\mathrm{cm}^{2}$ irradiance HINS-light has detrimental effects on osteoblast function, this may have no significant bearing on bone formation or osseointegration of implants during use of the light in a surgery environment. Light of $405 \mathrm{~nm}$ wavelength will not penetrate deeply into bone. Penetration of the visible light spectrum into tissue increases with wavelength, with red light penetrating the skin to $6 \mathrm{~mm}$, and shorter wavelength blue light only penetrating up to $2 \mathrm{~mm}$ (Fernandez-Guarino et al., 2007). Macrene (2006) also showed that $50 \%$ of red light photons (wavelength $800 \mathrm{~nm}$ ) would penetrate $20 \mathrm{~mm}$ into soft tissue, compared with $80 \mu \mathrm{m}$ for photons of $255 \mathrm{~nm}$ UV light. Although data on the penetration of blue light are not available, porcine studies have shown that a $4.3 \mathrm{~mW} / \mathrm{cm}^{2}$ laser of $635 \mathrm{~nm}$ light penetrates $1.6 \pm 0.4 \mathrm{~mm}$ into trabecular bone (Bisland and Burch, 2006). Any damage to osteoblasts in this context would therefore only occur on the bone surface, and would have only limited effects on osseointegration of an implant. Osseointegration is not a surface process and, during total hip replacement, osseointegration of the femoral stem will take place deep within the cavity of the bone, where exposure to $405 \mathrm{~nm}$ HINS-light will be minimal. It is therefore unlikely that $405 \mathrm{~nm}$ HINS-light at the intensities and duration used in this study would cause any significant delay in osseointegration of implants.

It was important to establish that, whilst being nondetrimental to the osteoblast cells, exposure to $5 \mathrm{~mW}$ / $\mathrm{cm}^{2} 405 \mathrm{~nm}$ HINS-light for $1 \mathrm{~h}$ was capable of inducing a bactericidal effect on bacterial contamination. $S$. aureus and $S$. epidermidis were selected for use due to their significance as causative pathogens of arthroplasty infections (Hamilton and Jamieson, 2008; Wilson et al., 2008), and at this dose bacterial kill of $98.1 \%$ and $83.2 \%$ were obtained, respectively, demonstrating a potent bactericidal effect against the culture collection isolates. The bactericidal efficacy of HINS-light against clinical isolates from infected hip and knee arthroplasty tissue from the Southern General hospital in Glasgow was convincingly shown for a range of Gram-positive and Gram-negative bacteria. A comparison of the inactivation 
Table 1. Analysis of osteoblast SEM images. $n \geq 6$ independent experiments, where each sample contained at least 15 cells. * signifies significant difference from control $(p<0.05$, ANOVA followed by Dunnett's comparison).

\begin{tabular}{|c|c|c|}
\hline Sample & \% viable cells $( \pm$ SEM) & Surface area $\left(\boldsymbol{\mu m ^ { 2 } \pm \text { SEM) }}\right.$ \\
\hline Control $($ no exposure) & $81 \pm 0.1$ & $84.7 \pm 12.9$ \\
\hline $5 \mathrm{~mW} / \mathrm{cm}^{2}$ for $1 \mathrm{~h}$ & $77 \pm 2.6$ & $53.0 \pm 13.2$ \\
\hline $15 \mathrm{~mW} / \mathrm{cm}^{2}$ for $1 \mathrm{~h}$ & $66 \pm 3.7 *$ & $31.5 \pm 8.5 *$ \\
\hline
\end{tabular}

Table 2. Inactivation of $S$. aureus and $S$. epidermidis on agar surfaces following exposure to $5 \mathrm{~mW} / \mathrm{cm}^{2}$ $405 \mathrm{~nm}$ HINS-light for $1 \mathrm{~h}\left(18 \mathrm{~J} / \mathrm{cm}^{2}\right)$. * indicates statistically significant reduction $(p<0.05$, ANOVA, $n=6$ independent experiments \pm SEM).

\begin{tabular}{|c|c|c|c|}
\hline Bacteria & $\begin{array}{c}\text { Initial Population } \\
\text { (mean CFU/plate } \pm \text { SD) }\end{array}$ & $\begin{array}{c}\text { Final Population } \\
\text { (mean CFU/plate } \pm \text { SD) }\end{array}$ & \% reduction \\
\hline S. aureus & $312.3( \pm 22.78)$ & $6.0( \pm 3.69)$ & $98.1 \%( \pm 1.1)^{*}$ \\
\hline S. epidermidis & $70.3( \pm 9.07)$ & $11.5( \pm 5.82)$ & $83.2 \%( \pm 8.7)^{*}$ \\
\hline
\end{tabular}

rates of the Gram-positive and Gram-negative bacteria reveals that, as reported previously (Maclean et al., 2009), Gram-positive bacteria are more susceptible to $405 \mathrm{~nm}$ HINS-light. The use of higher intensities of $405 \mathrm{~nm}$ HINSlight to kill the clinical isolates proves the principle that clinical isolates as well as type cultures can be killed, and demonstrates that faster cell kill can be achieved with higher intensities of $405 \mathrm{~nm}$ HINS-light.

The experiments described in this study were carried out under closely defined laboratory test conditions and have established critical dose levels for safe exposure of osteoblast tissue to $405 \mathrm{~nm}$ light. For practical application, this dose level will be dependent on the irradiance from the light source, the distance from the treated tissue and the exposure time. It is anticipated that for the proposed practical application, $405 \mathrm{~nm}$ disinfecting light systems would have brightness characteristics similar to typical operating theatre lighting. Further work, involving close interaction with surgical staff, is required to translate these findings into the optimal design of a light-delivery system, which could potentially have application for directed continuous disinfection of the operating environment during real-time arthroplasty surgery.

\section{Conclusions}

$405 \mathrm{~nm}$ HINS-light exposure for $1 \mathrm{~h}$ at $5 \mathrm{~mW} / \mathrm{cm}^{2}$ does not significantly alter osteoblast morphology, function or viability. It is an effective bactericide for clinically relevant bacteria and was found to kill $98.1 \%$ of Staphylococcus aureus and $83.2 \%$ of Staphylococcus epidermis populations at this dose. These findings, along with the limited penetration of the light into tissues, suggest that $405 \mathrm{~nm}$ HINS-light at this exposure level could potentially be used for directed environmental disinfection in orthopaedic operating theatres. In fact, osteoblasts exposed to $5 \mathrm{~mW} / \mathrm{cm}^{2}$ for up to $2 \mathrm{~h}$ showed no loss of viability. For localised short duration exposure, such as during high risk surgical procedures, $405 \mathrm{~nm}$ HINS-light has potential to be used to reduce the number of airborne and surface bacteria in the area immediately surrounding a surgical site without damaging the exposed tissues, analogous to the results from environmental disinfection procedures already demonstrated in the Burns Unit of Glasgow Royal Infirmary. This visible lightbased technology has the potential significantly to reduce contamination, and consequently infection, in arthroplasty, and has applications in many diverse areas of surgery, particularly where medical devices are being introduced into the body.

\section{Acknowledgements}

RMD and PR were supported by EPSRC Medical Devices DTC scholarships. The authors acknowledge the support of Mrs Katie Henderson and Mr David Currie in mammalian cell and bacterial culture experiments.

\section{References}

Anderson JG, Maclean M, Woolsey GA, MacGregor SJ (2006) Inactivation of Gram positive bacteria. Granted UK patent GB2442705B.

Anderson JG, Maclean M, Woolsey GA, MacGregor SJ (2007) Light inactivation of Gram positive bacteria. International Patent Application WO 2007/012875A1.

Bisland, SK, Burch S (2006) Photodynamic therapy of diseased bone. Photodiagnosis Photodyn Ther 3: 147-155.

Blatchley III E R, Peel MM (1991) Disinfection by ultraviolet irradiation. In Disinfection, Sterilisation and Preservation, 4th Ed (Block SS, ed), Lea \& Febiger, Philadelphia, pp. 823-851.

Carpenter TO, Moltz KC, Ellis B, Andreoli M, McCarthy TL, Centrella M, Bryan D, Gundberg CM (1998) Osteocalcin production in primary osteoblast cultures 
derived from normal and hyp mice. Endcrinology 139: 35-43.

Davis N, Curry A, Gambhir AK, Panigrahi H, Walker CRC, Wilkins EGL, Worsley MA, Kay PR (1999) Intraoperative bacterial contamination in operations for joint replacement. J Bone Joint Surg [Br] 81B: 886-889.

Ducy P, Desbois C, Boyce B, Pinero G, Story B, Dunstan C, Smith E, Bonadio J, Goldstein S, Gunberg C, Bradley A, Karsenty G (1996) Increased bone formation in osteocalcin-deficient mice. Nature 382: 448-452.

Fernandez-Guarino M, Garcia-Morales I, Harto A, Montull C, Perez-Garcia B, Jaen P (2007) Photodynamic therapy: New indications. Actas Dermosifiliogr 98: 377 395.

Gosden, PE, MacGowan AP, Bannister GC (1998) Importance of air quality and related factors in the prevention of infection in orthopaedic implant surgery. J Hosp Infect 39: 173-180.

Grzelak A, Rychlik B, Bartosz G (2001) Light dependent generation of reactive oxygen species in cell culture media. Free Rad Biol Med 30: 1418-1425.

Guffey JS, Wilborn J (2006) In vitro bactericidal effects of $405 \mathrm{~nm}$ and $470 \mathrm{~nm}$ blue light. Photomed Laser Surg 24: 684-688.

Hamilton H, Jamieson J (2008) Deep infection in total hip arthroplasty. Can J Surg 51: 111-117.

Hoemann CD, El-Gabalawy H, McKee MD (2009) In vitro osteogenesis assays: Influence of the primary cell source on alkaline phosphatise activity and mineralisation. Pathologie Biologie 57: 318-323.

Khadra M, Lyngstadaas SP, Haanaes HR, Mustafa K (2005) Effect of laser therapy on attachment, proliferation and differentiation of human osteoblast-like cells cultured on titanium implant material. Biomaterials 26: 3503-3509.

Klevens RM, Edwards JR, Richards CL Jr, Horan TC, Gaynes RP, Pollock DA, Cardo DM (2007) Estimating health care-associated infections and deaths in U.S. hospitals, 2002. Public Health Rep 122: 160-166.

Lowry OH, Rosebrough NJ, Farr AL, Randall RJ (1951) Protein measurement with the Folin phenol reagent. J Biol Chem 193: 265-275.

Maclean M, MacGregor SJ, Anderson JG, Woolsey GA (2008a) High-intensity narrow-spectrum light inactivation and wavelength sensitivity of Staphylococcus aureus. FEMS Microbiol Lett 285: 227-232.

Maclean M, MacGregor SJ, Anderson JG, Woolsey GA. (2008b) The role of oxygen in the visible-light inactivation of Staphylococcus aureus. J Photochem Photobiol B 90: 180-184.

Maclean M, MacGregor SJ, Anderson JG, Woolsey GA (2009) Inactivation of bacterial pathogens following exposure to light from a 405-nanometer light-emitting diode array. Appl Environ Microbiol 75: 1932-1937.

Maclean M, MacGregor SJ, Anderson JG, Woolsey GA, Coia JE, Hamilton K, Taggart I, Watson SB, Thakker B, Gettinby G (2010) Environmental decontamination of a hospital isolation room using high-intensity narrowspectrum light. J Hosp Infect 76: 247-251.

Macrene AA (2006) Laser-mediated photodynamic therapy. Clin Dermatol 24: 16-25.
Marques MM, Pereira AN, Fujihara NA, Nogueira FN, Eduardo CP (2004) Effect of low power laser irradiation on protein synthesis and ultrastructure of human gingival fibroblasts. Laser Surg Med 34: 260-265.

Martinez P, Moreno I, De Miguel F, Vila V, Esbrit P, Martinez M (2001) Changes in osteocalcin response to 1,25-dihydroxyvitamin D[3] stimulation and basal vitamin D receptor expression in human osteoblastic cells according to donor age and skeletal origin. Bone 29: 35-41.

McDonald R, MacGregor SJ, Anderson JG, Maclean M, Grant MH (2011) Effect of $405 \mathrm{~nm}$ high-intensity narrow-spectrum light on fibroblasts populated collagen lattices - an in vitro model of wound healing. J Biomed Optic Lett 16: 048003.

McGovern PD, Albrecht M, Belani KG, Nachtsheim, C, Partington PF, Carluke I, Reed MR (2011) An investigation of theatre ventilation, patient warming and joint replacement infection in orthopaedics. J Bone Joint Surg [Br] 93B: 1537-1544.

McGowan Jr JE (1983) Antimicrobial resistance in hospital organisms and its relation to antibiotic use. Rev Infect Dis 5: 1033-1048.

Nakamura S, Voleti PB, Baldwin KD, Lee GC (2009) Osteocalcin secretion as an early marker of in vitro osteogenic differentiation of rat mesenchymal stem cells. Tissue Eng Part C Methods 15: 169-180.

National Audit Office (2004) Improving patient care by reducing the risk of hospital acquired infection: A progress report. ISBN: 0102929157.

Orenstein A, Klein D, Kopolovic J, Winkler E, Mailik Z, Keller N, Nitzam Y (1997) The use of porphyrins for eradication of Staphylococcus aureus in burn wound infections. FEMS Immunol Med Microbiol 19: 307-314.

Owen TA, Aronow MS, Barone LM, Bettencourt B, Stein GS, Lian JB (1991) Pleiotropic effects of vitamin D on osteoblast gene expression are related to the proliferative and differentiated state of the bone cell phenotype: dependency upon basal levels of gene expression, duration of exposure, and bone matrix competency in normal rat osteoblast cultures. Endocrinology 128: 1496-1504.

Owers KL, James E, Bannister GC (2004) Source of bacterial shedding in laminar flow theatres. J Hosp Infect 58: 230-232.

Papageorgiou P, Katsambas A, Chu A (2000) Phototherapy with blue $(415 \mathrm{~nm})$ and red $(660 \mathrm{~nm})$ light in the treatment of acne vulgaris. Brit J Dermatol 142: 973-978.

Reilly J, Stewart S, Allardice G, Noone A, Robertson C, Walker A, Coubrough S (2008). Results from the Scottish National HAI Prevalence Survey. J Hosp Infect 69: 62-68.

Ridgeway S, Wilson J, Charlet A, Kafatos G, Pearson A, Coello R (2005) Infection of the surgical site after arthroplasty of the hip. J Bone Joint Surg [Br] 87: 844-850.

Ritter MA, Olberding EM, Malinzak RA (2007) Untraviolet lighting during surgery and the rate of infection. J Bone Joint Surg [Am] 89: 1935-1940.

Saracino S, Mozzati M, Martinasso G, Pol R, Canuto RA, Muzio G (2009) Superpulsed laser irradiation increases osteoblast activity via modulation of bone morphogenetic factors. Laser Surg Med 41: 298-304. 
Smith S (2009) Effect of novel electronic sterilisation methods on the components of hybrid collagen-based biomaterials. Eng D Thesis, University of Strathclyde, Glasgow, Scotland.

Stein A, Benayahu D, Maltz L, Oron U (2005) Low-level laser irradiation promotes proliferation and differentiation of human osteoblasts in vitro. Photomed Laser Surg 23: 161-166.

Stoien JD, Wang RJ (1974) Effect of near-ultraviolet and visible light on mammalian cells in culture II. Formation of toxic photoproducts in tissue culture medium by blacklight. Proc Natl Acad. Sci. USA 71: 3961-3965.

Von Eiff C, Becker KW, Jansen B (2005) Modern strategies in the prevention of implant-associated infections. Int J Artif Organs 28: 1146-56.
Walsh BJ, Thornton SC, Penny R, Breit SN (1992) Microplate reader-based quantitation of collagens. Anal Biochem 203: 187-190.

Wilson J, Charlett A, Leong G, McDougall C, Duckworth G (2008) Rates of surgical site infection after hip replacement as a hospital performance indicator: analysis of data from the English mandatory surveillance system. Infect Control Hosp Epidemiol 29: 219-226.

Editor's note: All questions and comments by the reviewers were answered by text changes. Hence there is no "Discussion with Reviewers" section. 